\title{
Physical, chemical, technological and toxicological characteristics of teiu potato flour (Jatropha elliptica (Pohl) Oken)
}

\author{
Juliana Aparecida Correia Bento ${ }^{1 *}$, Menandes Alves de Souza Neto1, Armando Garcia Rodriguez ${ }^{2}$, \\ Luiz Artur Mendes Bataus ${ }^{2}$, Márcio Caliari', Manoel Soares Soares Júnior ${ }^{1}$
}

${ }^{1}$ Food Science and Technology Department, Federal University of Goiás - UFG, CP 131, CEP 74690-900, Goiânia, Goiás, Brazil, ${ }^{2}$ Institute of Biological Sciences, Federal University of Goiás - UFG, CP 131, CEP 74690-900, Goiânia, Goiás, Brazil

\section{A B S T R A C T}

\begin{abstract}
Jatropha elliptica (Pohl) Oken, popularly known as teiu potato, is widely used in folk medicine as a purgative and in the treatment of snake bites. There is no scientific data on the physicochemical characterization or anti-nutritional compounds, nor are there any reports on the application of this root in the production of flours for food purposes. Thus, the objective of this work was to contribute with new knowledge concerning the production yield of teiu potato root flour, characterize its physical, chemical and technological properties, and determine its anti-nutritional and toxicological factors. The flour was obtained on three repetitions (batches) and all analyses were carried out in triplicate for each repetition. The flour production yield was $34.29 \%$, and the product obtained was an orange powder

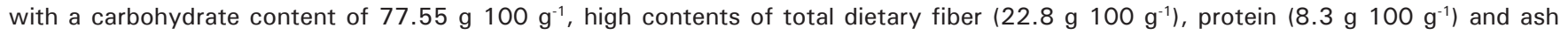

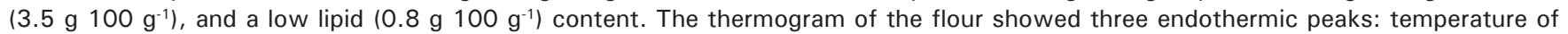
gelatinization of the flour starch $\left(77.42^{\circ} \mathrm{C}\right)$; glass transition $\left(106.55^{\circ} \mathrm{C}\right)$ and protein and lipid-amylose complexes $\left(131.77{ }^{\circ} \mathrm{C}\right)$. The flour presented antioxidant potential (89.59\% of DPPH discoloration), a high concentration of phenolic compounds (12.67 mg eq gallic acid $\left.100 \mathrm{~g}^{-1}\right)$, nitrates $\left(4.4 \mathrm{~g} \mathrm{Kg}^{-1}\right)$, tannins $\left(5.4 \mathrm{~g}\right.$ tannic acid $\left.100 \mathrm{~g}^{-1}\right)$ and trypsin inhibitors $\left(4.3 \mathrm{UTI} \mathrm{mg}^{-1}\right)$. The teiu potato flour requiring further, more profound studies before being indicated for human nutrition, due to the presence of anti-nutritional factors and the toxicity presented in the test with Artemia salina.
\end{abstract}

Keywords: Anti-nutritional factors; Antioxidants; Nitrates; Thermogram; Trypsin inhibitor

\section{INTRODUCTION}

The Euphorbiaceae family stands out as one of the largest in number of species, presenting great complexity and diversity. It offers great potential for use, with more than 1100 species and great prominence in economic activities, including its use as human food and in the production of medicines. Jatropha elliptica (Pohl) Oken is an herbaceous sub-shrub, popularly known in Brazil as "batata-de-teiú" or "erva-de-largato", translated as teiu potato for the purpose of this paper. It occurs naturally in the savanna of the Brazilian states of Goiás (GO), Maranhão (MA), Mato Grosso (MT), Mato Grosso do Sul (MS), Pará (PA) and the Federal District (DF) (Cordeiro and Secco, 2014). It is a plant of seasonal character, being observed mainly during the transition from the dry to the rainy seasons, and presents root tuberization (Trindade, 2015).
An evaluation of the chemical constituents of Jatropha plants resulted in the isolation of alkaloids, cyclic peptides, terpenes (monoterpenes, sesquiterpenes, diterpenes and triterpenes), flavonoids, lignins, coumarins, non-cyanogenic glycosides, phloroglucinols, ferollic esters, phenolic compounds and fatty acids (Sabandar et al, 2013).

The ethanolic extract of Jatropha elliptica has been widely used in popular medicine as a purgative and in the treatment of snake bites. Jatropha elliptica (Pohl) Oken presented a high content of phenolic compounds which are responsible for the medicinal anti-inflammatory properties and can neutralize the neurotoxicity in vitro and the myotoxicity of Bothrops jararacussu venom (Ferreira-Rodrigues et al, 2016). The teiu potato also has antimicrobial activity, attributed to the presence of saponins, which cause cell rupture in

\footnotetext{
${ }^{*}$ Corresponding author:

Juliana Aparecida Correia Bento, Food Science and Technology Department, Federal University of Goiás - UFG, CP 131, CEP 74690-900, Goiânia, Goiás, Brazil. Tel.: +55 (62) 35211611. E-mail: julianaap.ufg@gmail.com
}

Received: 04 January 2019; Accepted: 30 March 2019 
microbial communities and are composed of steroidal or triterpenic glycosides with good foaming ability. The antimicrobial activity of the extract was proven against E. coli and S. aureus resistant strains. Jatropha elliptica (Pohl) Oken extracts present penta-substituted pyridine, a compound that potentiates the activity of ciprofloxacin and norfloxacin, which show bacteriostatic action (Marquez et al, 2005).

In addition, the plant presents potential for human consumption, since its extract did not present cyanogenic glycosides or hemolytic activity (Ferreira-Rodrigues et al, 2016). However, there are no reports in the literature on the use of or the physicochemical characteristics of the flour obtained from teiu potato roots. The objective of this research was to contribute with new knowledge about the production yield of teiu potato flour, to characterize its physical, chemical and technological properties, and to determine any anti-nutritional and toxicological factors.

\section{MATERIAL AND METHODS}

\section{Material and flour processing}

The Jatropha elliptica (Pohl) Oken roots were harvested $(15 \mathrm{~kg})$ from a pasture in the municipality of Mara Rosa, GO, Brazil (-14.05938, -49.369186) in July 2016, fruiting season of this wild plant. The roots were placed in low density polyethylene packages and maintained at $6 \pm 1^{\circ} \mathrm{C}$ during transport and up to the time of processing. In the laboratory,

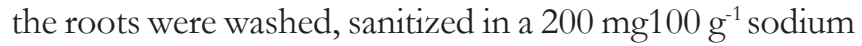
hypochlorite solution for $15 \mathrm{~min}$, peeled, weighed, cut into slices, and dried in an air circulation oven at $35^{\circ} \mathrm{C}$ for $48 \mathrm{~h}$. The dehydrated material was passed through a knife mill equipped with $2.0 \mathrm{~mm}$ sieves.

\section{Physical and chemical characteristics}

The moisture content was quantified in an oven at $105^{\circ} \mathrm{C}$ up to constant weight, ash by weighing after incineration at $550^{\circ} \mathrm{C}$ in a muffle furnace, the nitrogen content by the micro-Kjeldahl method and then multiplied by a factor of 6.25 to obtain the crude protein content, the lipids by extraction with petroleum ether PA in a Soxhlet apparatus, total dietary fiber by the enzyme-gravimetric method, and total carbohydrates by difference, according to (AOAC, 2012) recommendations. The energy value $\left(\mathrm{kJ} \mathrm{g}^{-1}\right)$ was calculated by multiplying the mass ( $\mathrm{g}$ ) of the digestible carbohydrates (total carbohydrates less insoluble dietary fiber) and protein by 4 , and the mass of the lipids by 9 . The total reducing and non-reducing soluble sugars were determined according to (Miller, 1959), where the principle is the reduction of 3,5-dinitro salicylic acid to 3-amino5-nitro-salicylic acid, reading in a spectrophotometer at $540 \mathrm{~nm}$, using a PA glucose solution as the standard. The water activity (Aw) was read in digital equipment (AquaLab, Series 3TE, Pullman, USA) coupled to a thermostatic bath at $25^{\circ} \mathrm{C}$, the $\mathrm{pH}$ with a potentiometer, with insertion of the electrode directly into $5 \mathrm{~g}$ of sample diluted in $100 \mathrm{~mL}$ of water, the total acidity by titration with $0.1 \mathrm{~N} \mathrm{NaOH}$ and the total soluble solids ( ${ }^{\circ} \mathrm{Brix}$ ) in a digital refractometer, as recommended by (AOAC, 2012). All analyses were carried out on three batches of flour (replicates) with three analyses for each batch (triplicate).

\section{Instrumental color}

The instrumental color parameters were analyzed using a colorimeter (Bankinh Meter Minolta, BC-10, Ramsey, USA), and from the values for $\mathrm{a}^{*}$ and $\mathrm{b}^{*}$, chroma (hue saturation) and Hue angle or matrix.

\section{Solubility in water and absorption of water and oil}

The water solubility index (WSI), water absorption index (WAI) and oil absorption index (OAI) were determined according to (Anderson, 1969), with water being replaced by oil for the OAI. The $2.5 \mathrm{~g}$ samples were weighed into previously tared centrifuge tubes and $30 \mathrm{~mL}$ of distilled water added. The tubes were shaken in a water bath for $30 \mathrm{~min}$ at $25^{\circ} \mathrm{C}$ and then centrifuged at $3500 \mathrm{~g}$ for $15 \mathrm{~min}$. The supernatants were carefully removed into $10 \mathrm{~mL}$ volumetric flasks and evaporated. The result of WAI was expressed in $g$ of precipitate per $g$ of dry matter. The WSI was calculated from the ratio between the mass of the dry residue of the supernatant (evaporation residue) and the weight of the sample.

\section{Thermal properties (DSC)}

Samples of $2 \mathrm{mg}$ (dry basis) were weighed into aluminum pans suitable for the differential scanning calorimeter (TA Instruments, Q20, Newcastle, UK) according to methodology described by (Weber et al, 2009). Distilled water $(6 \mu \mathrm{L})$ was added to the sample, which was sealed in a specific press. The sealed samples were held for $12 \mathrm{~h}$ at room temperature, and then heated in the range from 40 to $160^{\circ} \mathrm{C}$ at a heating rate of $10^{\circ} \mathrm{Cmin}^{-1}$. The temperatures at the onset, the peak and the conclusion of gelatinization, and the enthalpy of gelatinization were calculated from the curve obtained, as well as the glass transition temperature $(\mathrm{Tg})$, using a TA Universal Analysis instrument (TA Instruments, Newcastle, UK).

\section{Phenolic compounds and antioxidant capacity}

The total phenolic compound content was determined using the Folin-Ciocalteau reagent and a spectrophotometer at $740 \mathrm{~nm}$. The data were expressed as milliequivalents of gallic acid per $100 \mathrm{~g}$ of sample (Waterhouse, 2002). The antioxidant capacity was determined by the DPPH method (Brand-Williams et al, 1995), based on the capture of the DPPH (2,2-diphenyl-1-picryl-hydrazyl) radical 
by antioxidants, producing a decrease in absorbance at $517 \mathrm{~nm}$.

\section{Toxicity test with Artemia salina}

A toxicity test with Artemia salina was carried out according to the methodology of (Meyer et al, 1982), with adaptations. A $30 \mathrm{gL}^{-1}$ solution of sea salt was prepared by adjusting the $\mathrm{pH}$ value to between 8.0 and 9.0 with 0.1 molL $^{-1} \mathrm{NaOH}$. This was used to hatch the eggs after $48 \mathrm{~h}$ under illumination and constant aeration at $25^{\circ} \mathrm{C}$, and in the preparation of the other dilutions. Ten larvae were transferred to tubes containing $1 \mathrm{ml}$ of saline and an aqueous teiu potato extract at concentrations between 0 and $100 \mu \mathrm{LmL}^{-1}$. The assay was carried out on three samples (replicates), and the live and dead animal counts carried out after $24 \mathrm{~h}$.

\section{Anti-nutritional factors}

The activity of the trypsin inhibitor was determined using the spectrophotometric method described by (Kakade et al, 1974), and the results expressed in $\mathrm{UTImg}^{-1}$. One trypsin unit (UTI) was defined as an increase of 0.01 absorbance units at $410 \mathrm{~nm}$ per $10 \mathrm{~mL}$ of reaction mixture. The nitrate content was determined by a colorimetric method according to (Cataldo et al, 1975). The tannin content was quantified according to the colorimetric method recommended by (AOAC, 2012) where the intensity of the blue color produced in the reduction of the Folin-Denis reagent by tannins was measured in a spectrophotometer at $760 \mathrm{~nm}$. The results were expressed in $\mathrm{g}$ of tannic acid per $100 \mathrm{~g}$ of sample.

\section{Statistical analysis}

The flour was obtained on three repetitions (batches) and all analyses were carried out in triplicate for each repetition. Descriptive statistics were used, and the means, standard deviations and coefficients of variation were calculated.

\section{RESULTS AND DISCUSSION}

\section{Yield, color and physicochemical properties}

The teiu potato root (Fig. 1) had a moisture content of $68.63 \pm 2 \mathrm{~g} 100 \mathrm{~g}^{-1}$, and the flour processing yield was $34.29 \%$ (w.w.b.) in relation to the peeled roots. The results were similar to the yield of cassava flour, which generally varies from 25 to $35 \%$, depending on the variety and age of the crop (Cereda and Vilpoux, 2003).

The luminosity of the flour was between intermediate and clear, while the values of chromaticity coordinates tended to red $(+)$ and yellow $(+)$ (Table 1$)$, thus showing a light orange coloration. The value calculated for chroma $\left(\mathrm{C}^{*}\right)$ was expressive, that is, an intense color, and that of the hue angle was intermediate between $0^{\circ}$ (red) and $90^{\circ}$ (yellow) (Table 1), therefore orange shade. The flour coloring was due to the yellow and red pigments present in the teiu potato roots (Fig. 1), probably carotenoids. Thus, the orange color of the flour may confer a color alteration on the products in which it is employed.

The teiu potato flour showed a water activity of 0.46 and moisture content of $9.7 \mathrm{~g} 100 \mathrm{~g}$ (Table 1), indicating its stability during storage at room temperature. These parameters are directly related to the deterioration rate of the product, and the low values obtained for this flour indicate that the risk of deterioration caused by

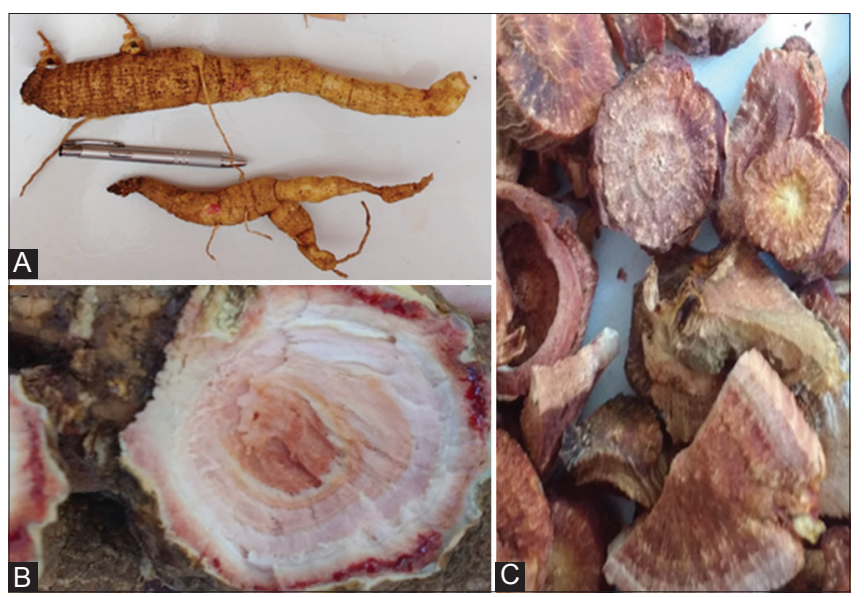

Fig 1. A: Teiu potato (Jatropha elliptica (Pohl) Oken) root; B: cut teiu potato root; C: pieces of roots after drying at $35^{\circ} \mathrm{C}$ for $24 \mathrm{~h}$.

Table 1: Physical and chemical characteristics and total energetic value of the teiu potato flour (Jatropha elliptica (Pohl) Oken) on a wet weight basis

\begin{tabular}{|c|c|c|c|}
\hline Components & Average & $\begin{array}{l}\text { Standard } \\
\text { deviation }\end{array}$ & CV (\%) \\
\hline Luminoisity & 76.62 & 0.73 & 0.95 \\
\hline$a^{*}$ & +11.39 & 0.40 & 3.51 \\
\hline$b^{*}$ & +14.94 & 0.51 & 3.41 \\
\hline Chrome & 18.79 & 0.63 & 3.33 \\
\hline Hue angle ${ }^{1}$ & 52.69 & 0.41 & 0.78 \\
\hline Water activity & 0.46 & 0.01 & 0.87 \\
\hline Moisture ${ }^{2}$ & 9.71 & 0.01 & 0.02 \\
\hline $\mathrm{Ash}^{2}$ & 3.53 & 0.01 & 0.03 \\
\hline Lipids $^{2}$ & 0.88 & 0.00 & 0.01 \\
\hline Protein $^{2}$ & 8.33 & 0.22 & 2.69 \\
\hline Carbohydrates $^{2}$ & 77.55 & 0.23 & 0.29 \\
\hline Total dietary fiber ${ }^{2}$ & 22.84 & 0.83 & 3.65 \\
\hline Unsoluble dietary fiber ${ }^{2}$ & 13.82 & 0.45 & 3.27 \\
\hline Soluble dietary fiber ${ }^{2}$ & 9.02 & 0.27 & 3.05 \\
\hline Total soluble sugars ${ }^{2}$ & 10.08 & 0.52 & 5.16 \\
\hline Soluble reducing sugars ${ }^{2}$ & 3.91 & 0.08 & 2.05 \\
\hline Total energy value ${ }^{3}$ & 12.39 & - & - \\
\hline Titratable acidity ${ }^{4}$ & 8.74 & 0.12 & 1.37 \\
\hline $\mathrm{pH}$ & 6.54 & 0.01 & 0.15 \\
\hline Water solubility inde $x^{2}$ & 15.74 & 0.47 & 2.98 \\
\hline Water absorption inde $x^{5}$ & 4.91 & 0.10 & 2.03 \\
\hline Oil absorption index ${ }^{6}$ & 2.13 & 0.04 & 1.88 \\
\hline
\end{tabular}

${ }^{1}$ grade $\left({ }^{\circ}\right) ;{ }^{2} \mathrm{~g} 100 \mathrm{~g}^{-1} ;{ }^{3} \mathrm{~J} \mathrm{~g}^{-1} ;{ }^{4} \mathrm{~g}$ of citric acid $100 \mathrm{~g}^{-1} ;{ }^{5} \mathrm{~g}$ of gel (g of sample) ${ }^{-1}$; ${ }^{6} \mathrm{~g}$ of precipitate ( $\mathrm{g}$ of sample) $)^{-1}$. 
microorganisms, enzymes or non-enzymatic reactions is minimal (Pellegrini et al, 2018).

The teiu potato flour also had low lipid and mineral contents, but the protein content was considerable

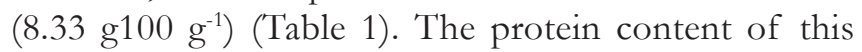
product was lower than the values reported for bean flours (22.3-26.7 g100 g-1) (Wani et al, 2013) and quinoa

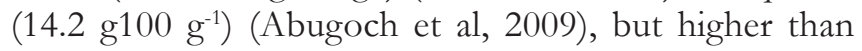
that of corn flour, 6.0-7.6 g100 g $\mathrm{g}^{-1}$ (Moreira et al, 2015). The protein content influences the absorption capacity and water solubility, and this functional characteristic is very important for the food industry as well as for the consumers in relation to the nutritional aspect.

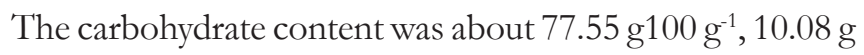
referring to the total soluble sugars, of which $3.91 \mathrm{~g}$ were reducing sugars (Table 1 ). Thus, probably the starch content, estimated by the difference between the total carbohydrate content $\left(77.55 \mathrm{~g} 100 \mathrm{~g}^{-1}\right)$ and the sum of the total dietary fiber $\left(22.84 \mathrm{~g}^{100 \mathrm{~g}^{-1}}\right)$ and the total soluble

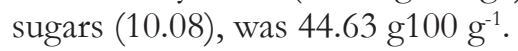

The teiu potato flour had a high content of dietary fiber (Table 1) when compared to green banana flour

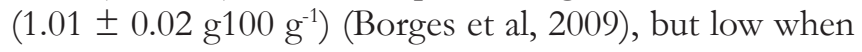
compared to the passion fruit peel meal $\left(66.37 \pm 0.71 \mathrm{~g}^{100 \mathrm{~g}^{-1}}\right)$ (de Souza et al, 2008).

The total energy value of the flour was $1.239 \mathrm{~kJ} 100$ $\mathrm{g}^{-1}$ (296.17 Cal100 $\mathrm{g}^{-1}$ ), a value lower than that presented by manioc flour (387 Cal100 g-1 $\mathrm{g}^{-1}$ (Ferreira et al, 2008). The potato flour solution had slightly acidic $\mathrm{pH}$ and titratable acidity of $8.74 \mathrm{~g}$ of citric acid $100 \mathrm{~g}^{-1}$ (Table 1), indicative of the presence of organic acidic compounds.

\section{Solubility in water and absorption of water and oil}

The teiu potato flour had a water solubility index (WSI)

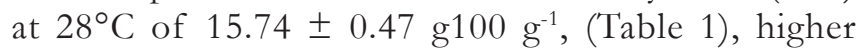
than the values determined for common bean flours

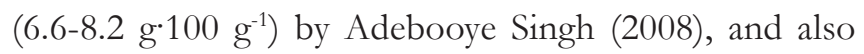
higher than the values determined for string flours

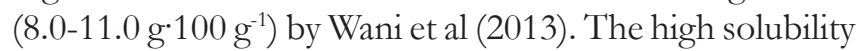
of the teiu potato flour is related to the high content of soluble sugars and soluble dietary fiber (Table 1). Flours with high WSI values may be used in foods that require low temperatures during their preparation (instantaneous), or in soups, desserts and sauces, which require ingredients with greater water solubility (Santana et al, 2017).

The water absorption index (WAI) at $28^{\circ} \mathrm{C}$ of the teiu potato flour was $4.91 \pm 0.10 \mathrm{~g}$ of gel ( $\mathrm{g}$ of sample $)^{-1}$ (Table 1), value higher than that found by Wani et al (2013) for raw bean flour (2.3 $\mathrm{g}$ of gel ( $\mathrm{g}$ of sample $\left.)^{-1}\right)$. A difference probably explained by the lower protein content of the teiu potato flour when compared to the bean flour, whose protein content was about $23.04 \mathrm{~g} \cdot 100 \mathrm{~g}^{-1}$ (Santiago-Ramos et al, 2018). The WAI represents the ability of the flour to associate with the water molecule (Shafi et al, 2016). Flours with high starch concentrations may show a favorable water absorption capacity, due to the high number of hydrophilic groups in the starch molecules, which provide greater softness and viscosity to food products (Aprianita et al., 2014). High carbohydrate and hydrophilic protein contents in flours also contribute to an increase in the capacity to absorb water, due to the strong hydrogen bonds of the polar or charged side chains (Prasad et al, 2012). On the other hand, a high lipid content in a flour contributes to a reduction in the WAI, impeding the hydration of starch granules with hydrophobic parts (Alcázar-Alay and Meireles, 2015). It can therefore be inferred that the high carbohydrate and protein concentrations of the teiu potato flour contributed to its high-water absorption capacity.

The oil absorption index (OAI) of the teiu potato flour was $2.13 \pm 0.04 \mathrm{~g}$ of precipitate ( $\mathrm{g}$ of sample) $)^{-1}$, lower than that found for passion fruit flours (2.35 $\mathrm{g}$ of precipitate ( $\mathrm{g}$ of sample $)^{-1}$ ) and linseed $\left.(2.75 \mathrm{~g} \text { of precipitate ( } \mathrm{g} \text { of sample })^{-1}\right)$, and higher than that of cassava bagasse $(0.59 \mathrm{~g}$ of precipitate (g of sample) $^{-1}$ ) (Fiorda et al, 2013; Santana et al, 2017). The OAI of flours varies according to the number of exposed hydrophobic groups on the proteins and the interaction of these with the hydrophobic chains of the fat (Porte et al, 2011). The teiu potato flour had a significant protein content (Table 1), favoring its oil absorption capacity.

\section{Thermal properties}

The differential scanning calorimetry (DSC) from 40 to $100^{\circ} \mathrm{C}$ curve of the teiu potato flour showed an endothermic peak characteristic of starch gelatinization (peak 1), with an initial temperature of $72.57 \pm 0.70{ }^{\circ} \mathrm{C}$, peak of $77.42 \pm 0.34^{\circ} \mathrm{C}$, and final temperature of $87.76 \pm$ $1.10^{\circ} \mathrm{C}$ (Fig. $2 \mathrm{~A}$ ), and the energy required for gelatinization of the starch present in the flour was $9.02 \pm 0.41 \mathrm{~J} \cdot \mathrm{g}^{-1}$. High gelatinization temperatures and enthalpy values are characteristic of protein and lipid-containing products interacting with starch granules (Cappa et al, 2018), which was verified in this study.

A second endothermic peak (peak 2) (Fig. 2B) was observed on the thermogram with an initial temperature of 106.20 $\pm 0.02^{\circ} \mathrm{C}$, peak temperature of $106.55 \pm 0.01^{\circ} \mathrm{C}$ and final temperature of $106.89 \pm 0.02^{\circ} \mathrm{C}$ (Fig. $2 \mathrm{~B}$ ), which referred to the glass transition of the material. In this temperature range, the amylose-lipid complexes probably degraded, and the protein probably denatured, which may have altered the physicochemical properties of the flour. 
Bento, et al.

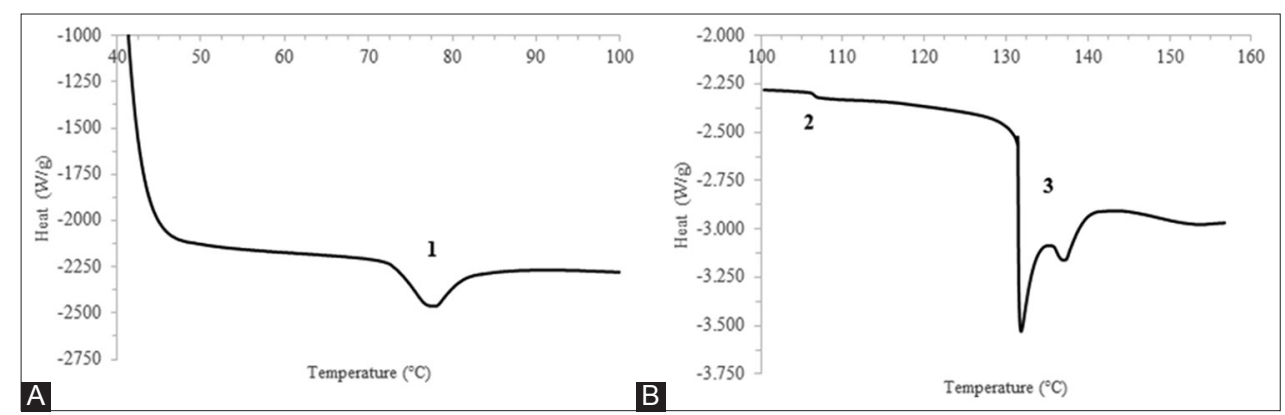

Fig 2. Differential Scanning Calorimetry of teiu potato (Jatropha elliptica (Pohl) Oken) root flour. A: thermogram from 40 to $100^{\circ} \mathrm{C}$; $\mathrm{B}$ : thermogram from 100 to $160^{\circ} \mathrm{C}$.

The third endothermic peak (peak 3) (Fig. 2B) started at 131.45 $\pm 0.01^{\circ} \mathrm{C}$, with its peak at $131.77 \pm 0.06^{\circ} \mathrm{C}$, final temperature at $141.85 \pm 0.07^{\circ} \mathrm{C}$ and enthalpy of $24.38 \pm 0.23 \mathrm{~J} \mathrm{~g}^{-1}$. The fact that the third peak had two consecutive and overlapping endotherms may be related to degradation of compounds with close transition temperatures, as observed in the denaturation of mixed protein complexes (Wen et al, 2012) and described for bean flour thermograms (Ekanayake et al, 2006). Wani et al (2013) that the high temperature of the third peak was due to complexation of lipid compounds with proteins and amylose, which increases the protein denaturation temperature.

\section{Antioxidant capacity and total phenolic compounds}

The extract obtained from the teiu potato flour showed a DPPH discoloration capacity of $89.59 \%$ (Table 2). DPPH is a stable radical used to measure the free radical scavenging ability of various plant products, as sweet orange juice (Giuffrè, et al., 2017c), edible vegetable oils (Giuffrè et al, 2017a; Giuffrè et al, 2017b) coffee (Yashin et al, 2013), guava fruit (Thaipong et al, 2006). Compared with the antioxidant capacity of wheat flour (18.76 - 22.97\%) (Abozed et al, 2014), teiu potato flour has high antioxidant capacity.

Phenolic compounds were also found in the teiu potato flour, with the methanolic extract showing the highest concentration $\left(12.67 \mathrm{mg} \mathrm{eq} \cdot \mathrm{g}^{-1}\right)$, followed by the aqueous extract and finally by the ethanolic extract (Table 2). Mumtaz Hamdani Ahmed Wani (2017) also verified that the methanolic extract of guar gum presented a higher concentration of phenolic compounds. The solvent polarity as well as the phenolic compounds present in the raw material influence the amounts of compounds extracted.

The phenolic compound concentration determined in wheat bran meal was $1.258 \mathrm{mg}$ eq gallic acid ${ }^{-1}$, this value being found in the methanolic-ethanolic extracts (Vaher et al, 2010), a value lower than that found in the teiu potato flour. Phenolic compounds are known to have essential medicinal and antioxidant properties and contribute to the
Table 2: Antioxidant capacity and phenolic compounds found in the different teiu potato (Jatropha elliptica (Pohl) Oken) extracts (wwb)

\begin{tabular}{lccc}
\hline Component & Average & $\begin{array}{c}\text { Standard } \\
\text { deviation }\end{array}$ & $\begin{array}{c}\text { Coefficient of } \\
\text { variation (\%) }\end{array}$ \\
\hline Antioxidant capacity $^{1}$ & 89.59 & 0.72 & 0.80 \\
Phenolic compounds $^{2}$ & - & - & - \\
Aqueous extract & 9.07 & 0.21 & 2.31 \\
Ethanolic extract & 4.42 & 0.21 & 4.75 \\
Methanolic extract & 12.67 & 0.67 & 5.28 \\
\hline
\end{tabular}

$1 \%$ of DPPH discoloration; ${ }^{2} \mathrm{mg}$ eq gallic acid ( $\mathrm{g}$ wet material $)^{-1}$.

physiological activity of various medicinal plants (Rajan et al, 2011). It can therefore be inferred that the medicinal activity presented by the teiu potato root may be derived from the high antioxidant activity and high phenolic compound content.

\section{Toxicity and antinutritional factors}

Solutions prepared with different concentrations of teiu potato flour presented different capacities to prevent the survival of Artêmia salina larvae (Fig. 3). The equation obtained from the graph showed that an extract concentration of $40.14 \mu \mathrm{L} \cdot \mathrm{mL}^{-1}(4.01 \%)$ caused the death of at least $50 \%$ of the animals.

The World Health Organization (WHO) considers that all substances that show 50\% mortality for Artemia salina larvae at concentrations below $0.1 \%$ are toxic (Meyer et al, 1982). Therefore, according to this criterion the teiu potato meal is not considered toxic. However, further studies are required to identify compounds that might be toxic and to carry out tests with rodents. The Artemia salina test is a good indicator for a toxicity study since it is fast, does not require approval by the Ethics Committee and shows no environmental impact (Lo Nostro et al, 2015).

The flour contained $0.44{\mathrm{~g} \cdot \mathrm{kg}^{-1}}^{-1}$ of nitrates (Table 3). By themselves, nitrates pose no risk, but after reaction their metabolites and products can imply adverse health effects. Nitrates may react with amines and form nitrosamines, which are potentially carcinogenic. In addition, the replacement of hemoglobin oxygen by nitrite may form 


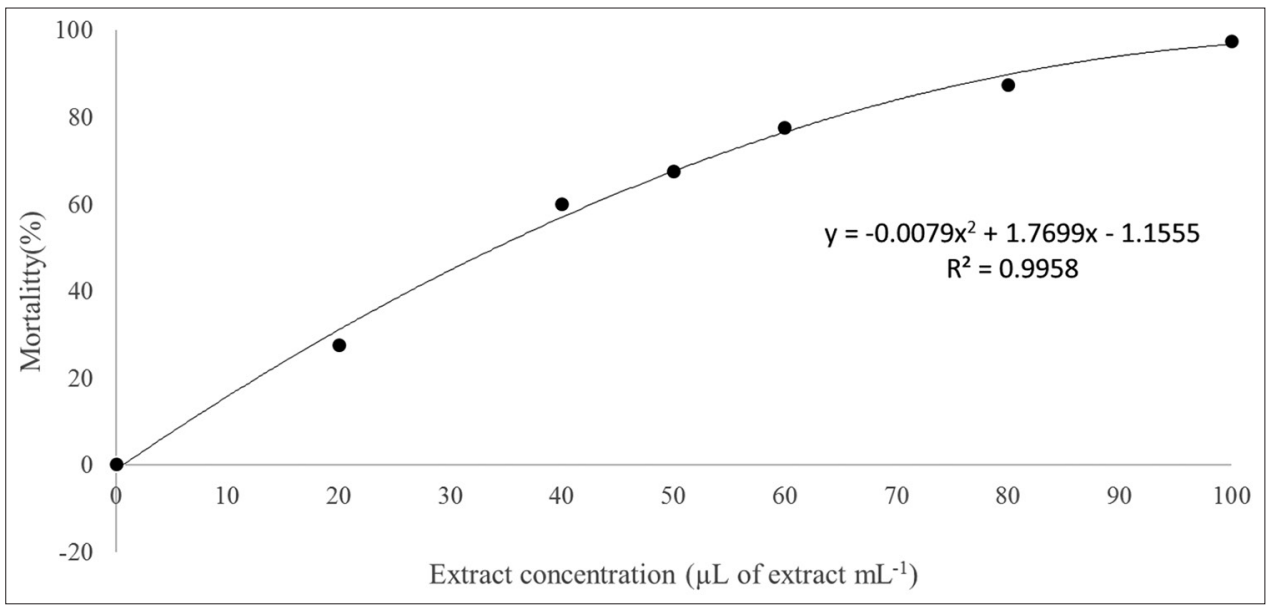

Fig 3. Mortality of Artemia saline larvae as a function of the aqueous teiu potato (Jatropha elliptica (Pohl) Oken) root flour extract concentration.

Table 3: Antinutritional factors in the teiu potato (Jatropha elliptica (Pohl) Oken) root flour (wwb)

\begin{tabular}{lccc}
\hline Factor & Average & $\begin{array}{c}\text { Standard } \\
\text { deviation }\end{array}$ & $\begin{array}{c}\text { Coefficient of } \\
\text { variation (\%) }\end{array}$ \\
\hline Nitrates $^{1}$ & 4.40 & 0.07 & 1.58 \\
Tannins $^{2}$ & 5.42 & 0.20 & 3.71 \\
Trypsin inhibitor $^{3}$ & 4.31 & 0.24 & 5.56 \\
\hline
\end{tabular}

${ }^{1} \mathrm{~g} \mathrm{Kg}^{-1} ;{ }^{2} \mathrm{~g}$ tannic acid $100 \mathrm{~g}^{-1} ;{ }^{3}$ trypsin inhibitor units $\mathrm{mg}^{-1}$.

methemoglobinemia, impeding the transport of oxygen to alveoli tissues, which can lead to death (Bahadoran et al, 2016; Steiner et al, 2011).

The World Organization for Food and Agriculture (FAO) and the World Health Organization (WHO) have established that a daily dose of $3.65 \mathrm{mg}$ of nitrate ion per $\mathrm{kg}$ of body weight is acceptable. The ingestion of a $100 \mathrm{~g}$ portion of teiu potato flour would provide a person weighing $70 \mathrm{~kg}$ with the equivalent of $6.28 \mathrm{mg}$ of nitrate, which is twice the daily recommendation by WHO. However, there are studies that show that nitrates can be beneficial to health, such as a reduction in the blood pressure with doses ranging from 6.15 to $19.8 \mathrm{mg} \cdot \mathrm{Kg}^{-1}$ (Bedale et al, 2016; Bryan and Ivy, 2015; Ghasemi and Jeddi, 2017).

The tannic acid content of the teiu potato root flour was $5.42 \mathrm{~g} \cdot 100 \mathrm{~g}^{-1}$ (Table 3), a very high value when compared to that found in string beans ( 0.114 to $\left.0.272 \mathrm{~g} \cdot 100 \mathrm{~g}^{-1}\right)$ (Landim et al, 2013). Tannins have also been found in Jatropha curcas L., which may hinder the use of this plant in animal feeds, since tannins have a high capacity to form insoluble protein complexes which form precipitates, inhibiting digestion of the proteins and amino acids (da Luz et al, 2013).

The flour had a low trypsin inhibitor content $4.314 \pm$ $0.24 \mathrm{mg}$ TIU mg $\mathrm{mg}^{-1}$ (Table 3) as compared to soybean meal $24.390 \pm 0.298 \mathrm{mg} \mathrm{TIU} \mathrm{mg}^{-1}$ (Andrade et al, 2016). Trypsin inhibitors are small proteins or polypeptides that may reduce the biological activity of proteolytic enzymes such as trypsin and chymotrypsin and may lead to the development of certain diseases in animals and humans. The inhibitory role of these compounds comes from their binding to trypsin and other proteins, inducing large conformational changes and causing protein aggregation and unfolding (Chanphai and Tajmir-Riahi, 2017; Jasti et al, 2014). Trypsin inhibitors may interfere with protein digestion and cause pancreatic disorders, but they are easily destroyed by heat (Li et al, 2017).

\section{CONCLUSION}

The teiu potato flour has interesting physical, chemical and technological characteristics, such as water solubility and water absorption capacity higher than those of raw bean flour, and an oil absorption capacity lower than that of passion fruit flour. These technological characteristics are suitable for use in baked goods. Moreover, the flour presented antioxidant potential and a higher phenolic compound concentration in the methanolic extracts. The presence of antioxidants contributes to the nutritional quality of the product, giving the product nutraceutical appeal. On the other hand, the presence of nitrates, tannins and trypsin inhibitors reduced its nutritional value. Thus, further studies are required to evaluate the potential of this product for later application in human food.

\section{ACKNOWLEDGMENTS}

The authors wish to thank CAPES (Coordenação de Aperfeiçoamento de Pessoal de Nível Superior) for the financial support.

\section{REFERENCES}

Abozed, S. S., M. El-kalyoubi, A. Abdelrashid and M. F. Salama. 2014. Total phenolic contents and antioxidant activities of 
various solvent extracts from whole wheat and bran. Ann. Agric. Sci. 59: 63-67.

Abugoch, L., E. Castro, C. Tapia, M C. Añón, P. Gajardo and A. Villarroel. 2009. Stability of quinoa flour proteins (Chenopodium quinoa Willd.) during storage. Int. J. Food. Sci. Technol., 44: 2013-2020.

Adebooye, O. C. and V. Singh. 2008. Physico-chemical properties of the flours and starches of two cowpea varieties (Vigna unguiculata (L.) Walp). Innov. Food. Sci. Emerg. Technol., 9: 92-100.

Alcázar-Alay, S. C. and M. A. A. Meireles. 2015. Physicochemical properties, modifications and applications of starches from different botanical sources. Food. Sci. and Tech., 35: 215-236.

Anderson, R. 1969. Gelatinization of corn grits by roll-and extrusioncooking and steaming. BiosynthasisNutr Biomed 22: 130-135.

Andrade, J. C., J. M. G. Mandarino, L. E. Kurozawa and E. I. Ida. 2016. The effect of thermal treatment of whole soybean flour on the conversion of isoflavones and inactivation of trypsin inhibitors. Food Chem. 194: 1095-1101.

AOAC. 2012. Official Methods of Analysis of the Association of Official Analytical Chemists: Association of Official Analytical Chemists (AOAC), Washington DC.

Bahadoran, Z., P. Mirmiran, S. Jeddi, F. Azizi, A. Ghasemi and F. Hadaegh. 2016. Nitrate and nitrite content of vegetables, fruits, grains, legumes, dairy products, meats and processed meats. J. Food Compos. Anal. 51: 93-105.

Bedale, W., J. J. Sindelar and A. L. Milkowski. 2016. Dietary nitrate and nitrite: Benefits, risks, and evolving perceptions. Meat Sci. 120: 85-92.

Borges, A. D. M., J. Pereira and E. M. Pereira. 2009. Caracterização da farinha de banana verde. Ciênc. Tecnol. Aliment., 29: 333-339.

Brand-Williams, W., M. E. Cuvelier and C. Berset. 1995. Use of a free radical method to evaluate antioxidant activity. LWT-Food Sci. Technol. 28: 25-30.

Bryan, N. S. and J. L. Ivy. 2015. Inorganic nitrite and nitrate: Evidence to support consideration as dietary nutrients. Nutr. Res. 35: 643-654.

Cappa, C., J. D. Kelly and P. K. W. Ng. 2018. Seed characteristics and physicochemical properties of powders of 25 edible dry bean varieties. Food Chem. 253: 305-313.

Cataldo, D., M. Maroon, L. Schrader and V. Youngs. 1975. Rapid colorimetric determination of nitrate in plant tissue by nitration of salicylic acid. Commun. Soil Sci. Plant. 6: 71-80.

Cereda, M. and O. Vilpoux. 2003. Culturas de tuberosas amiláceas Latino Americanas. tecnologia, Usos e Potencialidades de Tuberosas Amiláceas Latino Americanas. Vo. 3. Fundação Cargill, São Paulo.

Chanphai, P. and H. A. Tajmir-Riahi. 2017. Trypsin and trypsin inhibitor bind milk beta-lactoglobulin: Protein protein interactions and morphology. Int. J. Biol. Macromol. 96: 754-758.

Cordeiro, I. and R. Secco. 2014. Jatropha in Lista de Espécies da Flora do Brasil. Jardim Botânico do Rio de Janeiro, Rio de Janeiro.

da Luz, J. M. R., S. A. Paes, D. P. Torres, M. D. Nunes, J. S. da Silva, H. C. Mantovani and M. C. M. Kasuya. 2013. Production of edible mushroom and degradation of antinutritional factors in Jatropha biodiesel residues. LWT-Food Sci. Technol. 50: 575-580.

de Souza, M. W. S., T. B. O. Ferreira and I. F. R. Vieira. 2008. Centesimal composition and functional technological properties of passion fruit rind flour/composicao centesimal e propriedades funcionais tecnologicas da farinha da casca do maracuja. Alim. Nutr. 19: 33-37.

Ekanayake, S., B. M. Nair, N. G. Asp and E. R. Jansz. 2006. Effect of processing of sword beans (Canavalia gladiata) on physicochemical properties of starch. Starch Stärke. 58: 215-222.

Ferreira-Rodrigues, S. C., C. M. Rodrigues, M. G. Dos Santos, J. A. A. Gautuz, M. G. Silva, J. C. Cogo, C. Batista-Silva, C. P. Dos Santos, F. C. Groppo and K. Cogo-Müller. 2016. Antiinflammatory and antibothropic properties of Jatropha elliptica, a plant from Brazilian Cerrado biome. Adv. Pharm. Bull. 6: 573.

Ferreira, G. D. G., R. L. Oliveira, E. D. C. Cardoso, A. L. R. Magalhães and E. L. Brito. 2008. Valor nutritivo de co-produtos da mandioca. Rev. Bras. Saúde Prod. Anim. 8: 364-374.

Fiorda, F. A., M. S. S. Júnior, F. A. D. Silva, L R. F. Souto, M. V. E. Grossmann,. 2013. Farinha de bagaço de mandioca: Aproveitamento de subproduto e comparação com fécula de mandioca. Pesq. Agropec. Trop. 43: 408-416.

Ghasemi, A. and S. Jeddi. 2017. Anti-obesity and anti-diabetic effects of nitrate and nitrite. Nitric Oxide. 70: 9-24.

Giuffrè, A. M., M. Capocasale, C. Zappia and M. Poiana. 2017a. Influence of high temperature and duration of heating on the sunflower seed oil properties for food use and bio-diesel production. J. Oleo Sci. 66: 1193-1205.

Giuffrè, A. M., C. Zappia and M. Capocasale. 2017b. Effects of high temperatures and duration of heating on olive oil properties for food use and biodiesel production. iJ. Am. Oil Chem. Soc. 94: 819-830.

Giuffrè, A. M., C. Zappia and M. Capocasale. 2017c. Physicochemical stability of blood orange juice during frozen storage. Int. J. Food Prop. 20: 1930-1943.

Jasti, L. S., N. W. Fadnavis, U. Addepally, S. Daniels, S. Deokar and S. Ponrathnam. 2014. Comparison of polymer induced and solvent induced trypsin denaturation: The role of hydrophobicity. Colloids Surf. B. 116: 201-205.

Kakade, M., J. Rackis, J. McGhee and G. Puski. 1974. Determination of trypsin inhibitor activity of soy products: A collaborative analysis of an improved procedure. Cereal Chem. 51: 376-382.

Landim, L. D. S., E. Cunha, M. D. M. Araujo, K. Silva, M. D. M. Rocha and R. D. R. Moreira-Araújo. 2013. Conteúdo de Fenólicos Totais, Antocianinas, Taninos e Atividade Antioxidante de Três Cultivares de Feijão-Caupi. Paper Presented at the Embrapa Meio-Norte-Artigo em Anais de Congresso (ALICE).

Li, J., Q. Xiang, X. Liu, T. Ding, X. Zhang, Y. Zhai and Y. Bai. 2017. Inactivation of soybean trypsin inhibitor by dielectric-barrier discharge (DBD) plasma. Food Chem. 232: 515-522.

Lo Nostro, P., B. W. Ninham, E. Carretti, L. Dei and P. Baglioni. 2015. Specific anion effects in Artemia salina. Chemosphere. 135: 335-340.

Marquez, B., L. Neuville, N. J. Moreau, J. P. Genet, A. F. Dos Santos, M. C. C. De Andrade and A. E. G. Sant'Ana. 2005. Multidrug resistance reversal agent from Jatropha elliptica. Phytochemistry. 66: 1804-1811.

Meyer, B., N. Ferrigni, J. Putnam, L. Jacobsen, D. Nichols and J. L. McLaughlin. 1982. Brine shrimp: A convenient general bioassay for active plant constituents. Planta Med. 45: 31-34.

Miller, G. L. 1959. Use of dinitrosalicylic acid reagent for determination of reducing sugar. Anal. Chem. 31: 426-428.

Moreira, R., F. Chenlo and S. Arufe. 2015. Starch transitions of different gluten free flour doughs determined by dynamic thermal mechanical analysis and differential scanning calorimetry. Carbohyd. Polym. 127: 160-167.

Hamdani, A. M., I. A. Wani. 2017. Guar and Locust bean gum: Composition, total phenolic content, antioxidant and antinutritional characterisation. Bioact. Carbohydr. Dietary Fibre. 11: 53-59.

Pellegrini, M., R. Lucas-Gonzales, A. Ricci, J. Fontecha, J. Fernández- 
López, J. A. Pérez-Álvarez and M. Viuda-Martos. 2018. Chemical, fatty acid, polyphenolic profile, techno-functional and antioxidant properties of flours obtained from quinoa (Chenopodium quinoa Willd) seeds. Ind. Crops. Prod. 111: 38-46.

Porte, A., E. F. D. Silva, V. D. D. Almeida, T. X. D. Silva and L. H. M. Porte. 2011. Propriedades funcionais tecnológicas das farinhas de sementes de mamão (Carica papaya) e de abóbora (Cucurbita Sp). Rev. Bras. Prod. Agroind. 13: 91-96.

Prasad, K., Y. Singh A. Anil. 2012. Effects of grinding methods on the characteristics of Pusa 1121 rice flour. J. Trop. Agric. Food. Sci. 40: 193-201.

Rajan, S., M. Gokila, P. Jency, P. Brindha and R. Sujatha. 2011. Antioxidant and phytochemical properties of Aegle marmelos fruit pulp. Int. J. Curr. Pharm. Res. 3: 65-70.

Sabandar, C. W., N. Ahmat, F. M. Jaafar and I. Sahidin. 2013. Medicinal property, phytochemistry and pharmacology of several Jatropha species (Euphorbiaceae): A review. Phytochemistry. 85: 7-29.

Santana, G. S., J. G. de Oliveira Filho and M. B. Egea. 2017. Características tecnológicas de farinhas vegetais comerciais. Rev. Agric. Neotrop. 4: 88-95.

Santiago-Ramos, D., J. D. Figueroa-Cárdenas, J. J. VélesMedina and R. Salazar. 2018. Physicochemical properties of nixtamalized black bean (Phaseolus vulgaris L.) flours. Food Chem. 240: 456-462.

Shafi, S., I. A. Wani, A. Gani, P. Sharma, H. M. Wani, F. Masoodi, A. A. Khan and A. M. Hamdani. 2016. Effect of water and ether extraction on functional and antioxidant properties of Indian horse chestnut (Aesculus indica Colebr) flour. J. Food Meas. Charact. 10: 387-395.

Steiner, F., T. Zoz, V. Ruppenthal and M. M. Echer. 2011. Acúmulo de nitrato e produção de chicória (Cichorium endivia L.) submetida à adubação nitrogenada sob cultivo protegido. Rev. Acad.
Ciênc. Animal. 9: 19-26.

Thaipong, K., U. Boonprakob, K. Crosby, L. Cisneros-Zevallos and D. H. Byrne. 2006. Comparison of ABTS, DPPH, FRAP, and ORAC assays for estimating antioxidant activity from guava fruit extracts. J. Food Compost. Anal. 19: 669-675.

Trindade, M. T. 2015. Espécies úteis da família Euphorbiaceae no Brasil. Rev. Cubana Plant. Med. 19: 292-309.

Vaher, M., K. Matso, T. Levandi, K. Helmja and M. Kaljurand. 2010. Phenolic compounds and the antioxidant activity of the bran, flour and whole grain of different wheat varieties. Procedia Chem. 2: 76-82.

Wani, I. A., D. S. Sogi, A. A. Wani and B. S. Gill. 2013. Physicochemical and functional properties of flours from Indian kidney bean (Phaseolus vulgaris L.) cultivars. LWT Food Sci. Tech. 53: 278-284.

Waterhouse, A. L. 2002. Determination of total phenolics. Curr. Prot. Food Anal. Chem. 6: 1-8.

Weber, F. H., F. P. Collares-Queiroz and Y. K. Chang. 2009. Physicochemical, rheological, morphological, and thermal characterization of normal, waxy, and high amylose corn starches. Food Sci. Tech. 29: 748-753.

Wen, J., K. Arthur, L. Chemmalil, S. Muzammil, J. Gabrielson and Y. Jiang. 2012. Applications of differential scanning calorimetry for thermal stability analysis of proteins: qualification of DSC. J. Pharm. Sci. 101: 955-964.

World Health Organization. 2007. Report of a Joint WHO/FAO/UNU Expert Consultation. Protein and Amino Acid Requirements in Human Nutrition. Geneva: World Health Organization.

Yashin, A., Y. Yashin, J. Y. Wang and B. Nemzer. 2013. Antioxidant and antiradical activity of coffee. Antioxidants (Basel, Switzerland). 2: $230-245$. 